\title{
Preventing ways to minimize probabilities of corruption in LNGOs in Iraq
}

\author{
Amanj Lateef Kakahama \\ Master in Project management University of Liverpool
}

\begin{abstract}
Purpose: the fragile of economic and political situations, weakness and instability in any country is a potential suitable medium to create and develop corrupted environment. Corruption minimizes the opportunity to funding projects in corrupted working environment. Typically the traditional image of local none government organizations leads to trust them, meanwhile the possibility of conducting corruption in these organizations is not far away from the staff. For example some directors or supervisors cheat the staff and seduce them to burn rate acts to show progress in the project, some mangers want to involve the staff in corrupted acts. This research arranged to minimize the potential corruption opportunities in local none government organizations in Iraq.

Methodology: quantitative methodology was implemented. 29 questions plus participants`comment were arranged to be answered within 15 to 20 minutes. The collected data is primary data about the local none government organization current administration and professional state in Iraq.

Finding: Level of corruption could be noted in the local none government organizations and based on the collected data this corruption is result of: a) lack of comprehensive and professional code of conduct / internal policy and b) absent of best practice and international criteria in managing and producing organization issues at daily bases. Based on the participants feedbacks international none government organizations are recommended to support building professional work environment in the local none government organizations in Iraq.
\end{abstract}

Key words: Code of Conduct, Corruption, Internal policy, Local none government organization and transparency.

\section{Introduction:}

(Michel 2010) presented defining of corruption as purposely misusing of the public or private resources for personal advantage without considering the real goals of the allocated resources, anticipated benefits from that resources and neglecting the role of law, regulations and morns of the community. (Ben 2008), argued organizations should have the needed mechanism and tools to respond and prevent any illegal practices which include but not limited to corruption, meanwhile whenever a case of violation has been recorded and there is no efficient mechanism to tools to respond then addressing new legislation will be necessary. No value of legislations and laws if the organizations directors do not will or have the plan to fighting corruption. Weak laws and legislations are a good entrance to practicing corruption. (Michel 2010) the fragile of economic and political situations, weakness and instability in country are suitable mediums to create and develop corrupted environment (Aimao 2009). (Noel 2014) argued corruption minimizes the opportunity to funding projects in corrupted working environment. (INOOD) the image of NGOs leads to trust them; meanwhile possibility of conducting corruption is not far away from the staff. For example the managers or supervisors cheats the staff technically and seduce them to burn rate acts to show progress in the project, meanwhile the mangers want to involve the staff in corrupted acts (PCHA). (Michel 2010) combating corruption without enforced laws is not enough to get result, to have real result there should be a level of social morality that prevent corruption and plays role during implementing the laws against personal benefits. Having this morality leads the organization leaders to address efficient techniques and procedures 
to ensure healthy implementing to the processes more than ensuring blind implementing of makeup processes.

\section{Literature Review: 1.1 Corruption:}

According to Transparency International (TI) corruption is: "the abuse of entrusted power for private gain". (Noel 2014), (Beverlee 2015), (Adam 2012), (Ahmed 2009) defined corruption as act done for personal benefits based on utilizing the allocated resources illegally and justify these acts within official documents without considering the ethical standards. Corruption could be social or organizational (Michel 2010). (Helmut 2013) argued that corruption shatters the community and makes society members enemy to each others. (Tanja 2009) argued corruption is an awful action against human being as it leads to generate victims. (Adam 2012), the core point of corruption and most difficult part in dealing with this issue is when the policy makers, decisions makers and stockholders reflecting, translating and analyzing the organization policies, law and legislations according to their benefits. (Ahmed 2009) Corruption level and range are practical reflection of the capability of the political system, legislations and the applied procedures that run the country, the corporation or organization. Corruption significantly leads to product retaliation in human resource capacity. On the other hand corruption generates huge challenges ranged from abusing of authority, shrinking the opportunities, inequality, hiring systems and wages scales. (Ben 2008), argued that among the reasons of emerging corruption are competition and managing methodologies of the available resources. Directors held the responsibility of corruption in their work environments as much they do not establish efficient procedures to determine corrupting acts. (Hendi 2014), argued corruption has become as a culture in some public institutions and also become a rationalization for its members to engage in corrupted acts. To stop corruption having strong law is required (Helmut 2013). (Michel 2010), argued governments and society are directing connections and both sides are responsible for not controlling corruption. (Shinichiro 2001) argued there is a need to think and analyzing the causes of corruption before identifying as processes. (David 2006), mentioned to another dimension of corruption as it gives new definition of success in work and making achievement as it does not depend on qualification or capacity. In corruption work environment there is no clear definition of capability of ability of holding the responsibility and managing duties. (Adam 2012), argued a combination of three factors together lead to establish a corrupted case: benefits, perpetrator and lack of capable guardian, although what make the situation worse is transferring the corruption crime to repeated phenomenon in the community. (Ahmed 2009) confirming corruption cases lead to stop funding organizations or fund requesters. Comforting corruption is a global issue. It requires addressing and accepting comprehensive guidelines and agreement to be implemented by the involving parties. (Michel 2010) the practical state of processing corruption starts when an act done or pretended to be done, but without considering the ethical side in the processes. (INOOD) corruption merged from disagreement among leaders, absent of integrity, recruiting unqualified staff to guarantee accepting corrupting actions silently. Creating a suspicious workplace environment is good example of embracing corruption. When the selecting and deciding processes done within very limited information without taking into consideration the other members' contributions and feedbacks, the possibility of practicing corruption will merge rapidly. On the contrary as much the processes of delegating and sharing information will be implemented the possibility of corruption acts will be reduced. (Yong 2015) argued that corruption could be classified to three levels Black, Gray and white according to the level of the resulted damage, but this is a relatively classification. Meanwhile corruption has one face and it exists in one area and only in one area even it was made by different persons at different levels, the situation is clear abusing of low, power or authority for personal advantage which could be directly or indirectly, on the other hand the person who involves in gray or white corruption considered as Black corruption at his / her case as this is the limit of the corruption, from the other side of the story the person who has involved in Black corruption will certainly feel not guilty and see himself/ herself within the white level. (Michel 2010) corruption could be observed in principles. Arthur argued the need of merging ethics in business to prevent corruption; corruption in moral behaviors. Organization leaders and employees should be aware of the affects of corruption; corruption of people.

(Ben 2008) (Tanja 2009) argued that forcedly controlling the work environment directs the managers and lower employees to accept dealing illicitly and coexist with corruption silently. The staff easily can understand superiors`attitudes to direct them toward unethical and illegal behaviors. (Michel 2010) argued 
corruption has a deep impact on business corporations. Corruption leads to establishing and authorizing the non official procedures and permission the individual judgment on the applied procedures based on personal analyzing which eventually initiate from personal benefit background. (Tanja 2009) argued corrupted individuals strive to apply their acts without documentation and getting advantage from their authorities. They provide justifications, not sharing the information to enforce corrupted behaviors. (David 2006), argued corruption done based on personal justification of the current situation which leads to current and future benefits taking into consideration that this justification means jumping over the approved procedures and documented policies.

\subsection{Corruption and Organization:}

Personal judgment based on personal justification is sort of corruption (Beverlee 2015). (Michel 2010), argued not all individuals believe in necessity of applying ethics and norms responsibility in work. In corrupted environment having corrupted individuals will be understood and easily accepted. (Hendi 2014) argued when corruption is part of the organization mentality and working style, then not only the corrupted individuals thinking style or perpetrators will justified their designing or practicing of corruption respectively, on the contrary accepting others to this processes will be considered as silent support for corruption. (Michel 2010) corruption is a none-separated package; there is no little or huge corruption, no technical, geographical, economical reasons justify any sorts of corruption. Conducting corruption done due to personal benefits not else. (Tanja 2009) argued corruption actors look at their behaviors as accepted and mutual attitude among themselves and this practicing of corruption will last as much they have common acceptance on this issue. The corrupted individuals consider themselves as victims of the system and they will lose their personal benefits if they did not abide by the mangers' orders. Corrupted individuals get advantage from any limitation in the organization policies to perpetrate their corruption and giving legitimacy to their work or at least to deny any illegality and all corrupted partners in the corruption processes get benefits without exception. (David 2006) the lack of identifying a clear road map of addressing corruption by decision makers is considered as sort of chaos and disorder which in turn reflect into managing processes and later reduces the performance and profitability; squeeze the credibility of the organization in narrow position. Corruption erodes trust in the public institutions and no business will be grown inside corrupted systems (Noel 2014). (Adam 2012), Individuals committed corruption when the opportunity is exist. The temptation is satisfied and the activity of supervision is limited or absent. (Adam 2012) Supervision and oversight is not taken seriously. Silencing of whistleblowers, non-united vision and goals lead the organization to corruption. (INOOD) lack of internal control and difficulty in verification are among reasons to caused corruption. (Helmut 2013) non- spending money on right purpose purposely. In this regard observation recorded that part of the allocated fund to the humanitarian purpose spent on issues are not related to the program, but justified by the organization.

\subsection{Fighting Corruption:}

(Yong 2015) argued anti corruption efforts aim to filling the gaps that facilitate corruption acts. (PCHA) Policies and applied mechanisms are needed to properly prevent and efficiently manage reasons of corruption. (Ben 2008) argued to prevent corruption a clear rules and specific working principles armed by commitment from the director and whole staffs are required. Implementing the organizational guidelines properly is one of the ways to prevent personal opportunities against the organization goals. (Adam 2012), the observed corruption case may be only the appeared part of the ice berg of series cases of corruption that were not observed or uncovered yet. Meanwhile the danger of practicing corruption is expanded to be a normal norm if it was not stopped. (INOOD) corruption can be prevented by closing the ways that lead to this choice. Corruption acts should be uncovered at any time and by any means. The inability to inform about the corrupted persons and corruption cases should not be a reason to not share this information with others for seeking the transparency.

(Michel 2010) there is no ending of corruption without strong willing to finish it. (Asad 2009) argued that the current adapted methodologies are not an efficient to fighting corruption. (Ben 2008), argued having new position as CEO - Chief Ethics Officer which will be responsible to ensure considering the ethics throughout implementing the whole technical and mechanical processes, is necessary to minimizing and preventing future corruption in the organization. To ensure efficient work of CEO and effectiveness impact 
that person should work inside the organization but his / her appointing, reporting, paying salary, technical support and announcing of position must be covered by the donor directly to be secured from any nonprofessional internal pressure inside the organization. Having workable and supported law and regulation are needed to fighting corruption (Michel 2010). To reduce corruption in any environment having sort of political willing and commitment are essential, good identifying of corruption definition, fields of practice and results, efficient techniques to deter, enforcing ethics in the system. (Shinichiro 2001), argued similar concepts and suggested comprehensive prepared steps that eliminate corruption and durable awareness about ethics matters that refuse dealing or accepting corruption. (Adam 2012), argued good laws and institutional steps lead to reduce corruption. (INOOD) preventing corruption requires establishing sound internal controls, sharing the NGOs report externally and having the right systems and policies to ensure that the released fund and support are allocated properly. Installing an external monitoring system could be another useful mechanism to reducing corruption and securing the complaint staff against any potential offended acts internally inside the organization (PCHA).

(Tanja 2009) argued that implementing corruption by others does not give us the legitimacy to be corrupted. (Helmut 2013) argued good selecting processes lead to minimizing corruption: hiring people based on the capacity and performance leads to have responsible staff which in turn creates a maintained work environment. (Adam 2012) argued developing guidelines of the organization, focusing on moral issues and integrity values, professional and efficient communication, random testing and whistleblower position. Involving internal and external decision makers in formulating the origination polices related to the processes. (INOOD) creating an efficient and effective mechanism that enable the employees, vendors, customers, and others to confidentially report suspected behaviors or abuses. (PCHA) identified several cause to not controlling corruption as: do not adopting whistleblower mechanism, absent of complaint mechanisms, the ultimately power of Country Director and non- practicing of delegation of authorities.

\section{Methoodology:}

In this research quantitative methodology was implemented. A designed monkey survey was applied and mailed to participants listed in the researchers` mail box as involvers in humanitarian sector. 29 questions plus participants comment were organized to be answered within 15 to 20 minutes. The collected data is primary data and serves the research as the most updated and accurate data about the local none government organization current administration and professional state in Iraq. Participants were informed that they are free to withdraw at any stage in responding processes and their personal information will be anonymous.

\section{Results:}

The presented data is related to 138 respondents from different agencies and at different levels of responsibilities and sort of experiences who are worked/ work with LNGOs in Iraq.

1. Questions from 1 to 3are identified :

a. The sort of the organizations that worked/ work with the LNOs in Iraq: 112 International nongovernment organizations, 6 International government organizations and 20 Local nongovernment organization.

b. Position holder of the participants: 10 directors or similar, 38 managers, 80 Officers and 10 others: external consultant or temporary paid advisor.

c. The participant official role in the LNGOs: 4 donors, 8partners and 126 staff.

2. Questions from 4 to 10 are reflecting the percentage of participants` feedback, communication and information about the code of conduct in the LNGOs in Iraq. 
Table 1: Participants`answer on the code of conduct / internal policies in LNGOs in Iraq

\begin{tabular}{|c|c|c|c|c|c|}
\hline Questions & $\begin{array}{c}\text { Strongly } \\
\text { Agree }\end{array}$ & Agree & $\begin{array}{c}\text { I do } \\
\text { not } \\
\text { know }\end{array}$ & Disagree & $\begin{array}{l}\text { Strongly } \\
\text { Disagree }\end{array}$ \\
\hline $\begin{array}{l}\text { The LNGOs that you worked/work with as a (donor, partner or staff) has a } \\
\text { comprehensive code of conduct / internal policy that clearly explains } \\
\text { implementing the needed processes and procedures }\end{array}$ & 11.6 & 26.1 & 47.8 & 13.0 & 1.4 \\
\hline $\begin{array}{l}\text { The code of conduct / internal policy of the LNGOs that you worked/work } \\
\text { with as a (donor, partner or staff) reflects the real needs of } \\
\text { the organizations`activities }\end{array}$ & 13.0 & 10.1 & 36.2 & 24.6 & 15.9 \\
\hline $\begin{array}{l}\text { The code of conduct / internal policy of the LNGOs that you worked/work } \\
\text { with as a (donor, partner or employee) was prepared by qualified staff and } \\
\text { their biographies have been attached with the code of conduct / internal } \\
\text { policy. }\end{array}$ & 5.8 & 8.7 & 31.9 & 29.0 & 24.6 \\
\hline $\begin{array}{l}\text { The required reasons and processes of updating the code of conduct / } \\
\text { internal policy in the LNGOs that you are worked/work with as a (donor, } \\
\text { partner or employee) are clear and applicable }\end{array}$ & 5.8 & 10.1 & 49.3 & 27.5 & 7.2 \\
\hline $\begin{array}{l}\text { The field staffs of LNGOs that you worked/work with as a (donor, partner } \\
\text { or staff) contribute in developing and updating the code of conduct / } \\
\text { internal policy }\end{array}$ & 8.7 & 7.2 & 17.4 & 23.2 & 43.5 \\
\hline $\begin{array}{l}\text { The code of conduct / internal policy of the LNGOs that you worked/work } \\
\text { with as a (donor, partner or staff) directly answer the daily HR, } \\
\text { Procurement, Financial and other departments` activities requirements } \\
\text { without giving the chance of personal justifications }\end{array}$ & 4.3 & 26.1 & 18.8 & 24.6 & 26.1 \\
\hline $\begin{array}{l}\text { The code of conduct / internal policy of the LNGOs that you worked/work } \\
\text { with as a (donor, partner or staff) is updated regularly taking into } \\
\text { consideration the new challenges. }\end{array}$ & 4.3 & 31.9 & 29.0 & 21.7 & 13.0 \\
\hline
\end{tabular}

3. Question 11 was separated from above questions because the sort of answers are different:

Table 2: Participants`answer on reviewing code of conduct / internal policies of LNGOs in Iraq

\begin{tabular}{|l|c|c|c|c|}
\hline \multicolumn{1}{|c|}{ Question } & Year & $\begin{array}{c}\text { Every 3 } \\
\text { year }\end{array}$ & $\begin{array}{c}\text { Per } \\
\text { request }\end{array}$ & $\begin{array}{c}\text { I do not } \\
\text { know }\end{array}$ \\
\hline $\begin{array}{l}\text { The code of conduct / internal policy of the LNGOs that you worked/ work } \\
\text { with as a (donor, partner or staff) is reviewed every: }\end{array}$ & 7.2 & 17.4 & 42.0 & 33.3 \\
\hline
\end{tabular}

4. Questions from 12 to 19 show the percentage of individual assessing and reacting with cases of corruption in LNGOs in Iraq in case were observed.

Table 3: Participants` answer on assessing and reacting with case of corruption in LNGOs in Iraq

\begin{tabular}{|c|c|c|c|c|c|}
\hline Questions /Answers & $\begin{array}{l}\text { Strongly } \\
\text { Agree }\end{array}$ & Agree & $\begin{array}{l}\text { I do not } \\
\text { know }\end{array}$ & Disagree & $\begin{array}{l}\text { Strongly } \\
\text { Disagree }\end{array}$ \\
\hline $\begin{array}{l}\text { How do you assess this statement: " corruption is an act done for personal benefits } \\
\text { based on utilizing the allocated resources illegally and justify these acts within } \\
\text { official documents without considering the ethical standards". }\end{array}$ & 71.0 & 27.5 & 1.4 & & \\
\hline $\begin{array}{l}\text { Corruption in LNGOs that you worked/ work with as a (donor, partner or staff) is } \\
\text { perpetrated based on personal benefits }\end{array}$ & 40.6 & 47.8 & 8.7 & 2.9 & \\
\hline Corruption is affecting LNGOs reputation & 46.4 & 33.3 & 4.3 & 15.9 & \\
\hline Confirmed corruption cases reduce the opportunities of further fund in LNGOs & 46.4 & 34.8 & 14.5 & 4.3 & \\
\hline $\begin{array}{l}\text { Some directors and managers in LNGOs that you worked/work with as a (donor, } \\
\text { partner or staff) encourage and excuse corruption behaviors }\end{array}$ & 29.0 & 39.1 & 14.5 & 11.6 & 5.8 \\
\hline $\begin{array}{l}\text { Some directors and managers in LNGOs that you worked/ work with as a (donor, } \\
\text { partner or staff) accept corruption behaviors silently }\end{array}$ & 42.0 & 44.9 & 2.9 & 2.9 & 7.2 \\
\hline $\begin{array}{l}\text { In LNGOs that you worked/ work with as a (donor, partner or staff) corruption } \\
\text { behaviors could be observed easily }\end{array}$ & 27.5 & 33.3 & 17.4 & 20.3 & 1.4 \\
\hline $\begin{array}{l}\text { In LNGOs that you worked/ work with as a (donor, partner or staff) corruption } \\
\text { behaviors could be minimized }\end{array}$ & 21.7 & 46.4 & 17.4 & 13.0 & 1.4 \\
\hline
\end{tabular}


5. Questions from 20 to 23 show the percentage of the managerial directing behaviors and attitude in NGOs in Iraq based on participants experiences.

Table 4: Participants`answer on some of the managerial directing behaviors and attitude in LNGOs in Iraq based on participants experiences.

\begin{tabular}{|l|c|c|c|c|c|}
\hline \multicolumn{1}{|c|}{ Questions /Answers } & $\begin{array}{c}\text { Strongly } \\
\text { Agree }\end{array}$ & Agree & $\begin{array}{c}\text { I do not } \\
\text { know }\end{array}$ & $\begin{array}{c}\text { Disagree } \\
\text { Strongly } \\
\text { Disagree }\end{array}$ \\
\hline $\begin{array}{l}\text { Some directors and managers in LNGOs that you worked/ work with as a } \\
\text { (donor, partner or staff) will resign if corruption cases confirmed }\end{array}$ & 8.7 & 23.2 & 20.3 & 33.3 & 14.5 \\
\hline $\begin{array}{l}\text { Some directors and managers in the LNGOs that they worked/ work with } \\
\text { as a (donor, partner or staff) will stay even if corruption cases confirmed }\end{array}$ & 10.1 & 40.6 & 24.6 & 20.3 & 4.3 \\
\hline $\begin{array}{l}\text { The LNGOs that you worked/ work with as a (donor, partner or staff) do } \\
\text { not mind to receive fund from entities listed as corrupted }\end{array}$ & 10.1 & 47.8 & 14.5 & 17.4 & 10.1 \\
\hline $\begin{array}{l}\text { The LNGOs that you worked/work with as a (donor, partner or staff) do } \\
\text { not mind to deal with entities listed as corrupted }\end{array}$ & 4.3 & 50.7 & 18.8 & 15.9 & 10.1 \\
\hline
\end{tabular}

6. Questions from 24 to 29 are offering technical, administration and ethical recommendations, procedures and methodologies to prevent possibilities of corruption in LNGOs in Iraq.

Table 5: Participants`answer on recommendations to prevent possibilities of corruption in LNGOs in Iraq

\begin{tabular}{|l|c|c|c|c|}
\hline \multicolumn{1}{|c|}{ Questions /Answers } & $\begin{array}{c}\text { Strongly } \\
\text { Agree }\end{array}$ & $\begin{array}{c}\text { Igree } \\
\text { not } \\
\text { know }\end{array}$ & Disagree \\
\hline $\begin{array}{l}\text { In LNGOs that you worked/ work with as a (donor, partner or staff) conducting } \\
\text { periodical technical testing of the employees is an efficient technique to stop corruption } \\
\text { recruiting processes }\end{array}$ & 56.5 & 39.1 & 1.4 & 2.9 \\
\hline $\begin{array}{l}\text { In LNGOs that you worked/work with as a (donor, partner or staff), to enhance the } \\
\text { transparency during the technical testing processes the processes should be done in } \\
\text { coordination with an external third part identified by the donors. }\end{array}$ & 60.9 & 37.7 & 1.4 & \\
\hline $\begin{array}{l}\text { In LNGOs that you worked/work with as a (donor, partner or staff), appointing a } \\
\text { technical advisor from the donor to overview the transparency of the procedures will } \\
\text { control the corruption possibilities in the LNGOs }\end{array}$ & 47.8 & 50.7 & & 1.4 \\
\hline $\begin{array}{l}\text { In LNGOs that you worked/work with as a (donor, partner or staff), engaging a } \\
\text { technical member from the donors to recruitment panel will reduce corruption } \\
\text { possibilities in the employment processes or selecting the vendors. }\end{array}$ & 60.9 & 36.2 & 1.4 & 1.4 \\
\hline $\begin{array}{l}\text { Installing online complaint screens to submit corruption cases and to be reviewed } \\
\text { directly by HQ will control abusing of the authorities or misleading inside the LNGOs } \\
\text { that you worked/work with as a (donor, partner or staff) }\end{array}$ & 58.0 & 39.1 & 2.9 & \\
\hline $\begin{array}{l}\text { The relationship between the donors and the LNGOs that you worked/work with as a } \\
\text { (donor, partner or staff) should not be limited to financial support or reviewing the } \\
\text { annual reports. }\end{array}$ & 75.4 & 23.2 & 1.4 & \\
\hline
\end{tabular}

7. Reviewing questions from 4 to 11 shows that the high rate of the answers was collected under "I do not know "category.

Table 6: The high rate of points was recorded under "I do not know" answer

\begin{tabular}{|l|c|c|c|c|c|}
\hline \multicolumn{1}{|c|}{ Questions } & $\begin{array}{c}\text { Strongly } \\
\text { Agree }\end{array}$ & Agree & $\begin{array}{c}\text { I do not } \\
\text { know }\end{array}$ & Disagree & $\begin{array}{c}\text { Strongly } \\
\text { Disagree }\end{array}$ \\
\hline $\begin{array}{l}\text { The LNGOs that you worked/work with as a (donor, partner or staff) has a } \\
\text { comprehensive code of conduct / internal policy that clearly explains } \\
\text { implementing the needed processes and procedures }\end{array}$ & 16 & 36 & 66 & 18 & 2 \\
\hline $\begin{array}{l}\text { The code of conduct / internal policy of the LNGOs that you worked/work } \\
\text { with as a (donor, partner or staff) reflects the real needs of } \\
\text { the organizations`activities }\end{array}$ & 18 & 14 & 50 & 34 & 22 \\
\hline $\begin{array}{l}\text { The code of conduct / internal policy of the LNGOs that you worked/work } \\
\text { with as a (donor, partner or employee) was prepared by qualified staff and }\end{array}$ & 8 & 12 & 44 & 40 & 34 \\
\hline
\end{tabular}




\begin{tabular}{|l|c|c|c|c|c|}
\hline $\begin{array}{l}\text { their biographies have been attached with the code of conduct / internal } \\
\text { policy. }\end{array}$ & & & & & \\
\hline $\begin{array}{l}\text { The required reasons and processes of updating the code of conduct / } \\
\text { internal policy in the LNGOs that you are worked/work with as a (donor, } \\
\text { partner or employee) are clear and applicable }\end{array}$ & 8 & 14 & 68 & 38 & 10 \\
\hline $\begin{array}{l}\text { The field staffs of LNGOs that you worked/work with as a (donor, partner } \\
\text { or staff) contribute in developing and updating the code of conduct / } \\
\text { internal policy }\end{array}$ & 12 & 10 & 24 & 32 & 60 \\
\hline $\begin{array}{l}\text { The code of conduct / internal policy of the LNGOs that you worked/work } \\
\text { with as a (donor, partner or staff) directly answer the daily HR, } \\
\text { Procurement, Financial and other departments`activities requirements } \\
\text { without giving the chance of personal justifications }\end{array}$ & 6 & 36 & 26 & 34 & 36 \\
\hline $\begin{array}{l}\text { The code of conduct / internal policy of the LNGOs that you worked/work } \\
\text { with as a (donor, partner or staff) is updated regularly taking into } \\
\text { consideration the new challenges }\end{array}$ & 6 & 44 & 40 & 30 & 18 \\
\hline $\begin{array}{l}\text { The code of conduct / internal policy of the LNGOs that you worked/ work } \\
\text { with as a (donor, partner or staff) is reviewed every }\end{array}$ & 10 & 24 & 58 & 46 & \\
\hline \multicolumn{1}{|c|}{ Total answers } & 84 & 190 & 376 & 272 & 182 \\
\hline
\end{tabular}

\section{Discussion:}

The obtained results show reflect the previous and current experiences of dealing with the LNGOs in Iraq especially those who work in effectively Kurdistan Region of Iraq.

The analyzing processes to the collected data conducted according to classification the questions in the distributed survey among the participants.

1. The questions from 4 to 10 show the relationship between the donor and the LNGO and Code of Conduct/ Internal policy were tested to formulate how much the donors know about the LNGOs that they work worked with:

a) The percentage of the data showed that the reporting, monitoring and evaluating system between the participants and the engaged LNGOs according to their experiences are limited to official documents focus on explaining the financial and administration responsibilities between both partners. Absolutely documenting the financial, administration and procurement processes are very important and an essential success part in any project, but on the other hand such documents will not cover the implementing methodologies, the level of performance, the commitment towards morals and humanitarian values, the utilized tools and techniques at the daily level of operations.

b) The acceptance and supporting rates became lower when the survey developed to ask more specific information about the code of conduct / internal policy of the LNGOs and how it was formulated. Comparing the answers of question 4 and 5 with the rest questions from 6 to 10. Further intervention is needed to explore the practical capacity of the LNGOs.

c) The efficiency of LNOGs code of conduct/ internal policy should be reviewed and reformulated as the source of this code of conduct / internal policy and reflecting the real needs of developing the code of conduct / internal policy were not addressed and involved properly, the questions 6 and 8 respectively. The process of copy paste or preparing any general code of conduct / internal policies to obtain an official approval to run the organization does not mean that this code of conduct will match and effective for the organization daily work, meanwhile neglecting the field staff feedback to develop the code of conduct / internal policy will make the updating processes of code of conduct / internal policy is inefficient.

d) Question 11 showed that code of conduct / internal policy are reviewed per request (42\%) of 138 respondents, but in this regard the reviewing process of the implemented code of conduct / internal policies in LNGOs will not clearly identify the real needs as the feedback of field staff did not take into consideration.

As a general overview the answers trend to shift to disagree and strongly disagree areas as the questions became more specified and the answers became more identified. 
2. Corruption as theory or practical: questions from 12 to 19 examined the understanding of corruption concept and its impact on the daily work and implemented activities:

a) Majority of participants $(98 \%)$ agreed on corruption definition; meanwhile only (88\%) of the participants agreed that corruption perpetrated based on personal benefits. It's understood that the most affected factor to produce corruption is personal reasons.

b) According to the answers (79\%) of participants agreed that corruption is affecting the organization reputation; meanwhile (86\%) of participants agreed that some directors and managers in LNGOs that they worked/ work with as a (donor, partner or staff) accept corruption behaviors silently and this shows the gap between the theory and practical aspects of corruption concept in LNGOs which covered in this survey. The acceptance of corruption behaviors silently could be observed as the organization hires some staff under qualification or delaying recruiting processes purposely to hire an identified person previously. This behavior cold be noted also as the organization management build long-term relationship with one supplier and excusing their decision based on technical and logistic factors

3. The obtained answers from questions 16 and 18 showed that $(68 \%)$ agreed that some directors and managers in LNGOs that they worked/ work with as a (donor, partner or staff) encourage and excuse corruption behaviors and (60\%) agreed that in LNGOs that they worked/ work with as a (donor, partner or staff) corruption behaviors could be observed easily respectively. These results are supporting the obtained results from questions 5 and 6 that the LNGOs code of conduct / internal policy reflect the real needs and the code of conduct / internal policy were prepared by qualified staff respectively.

4. Corruption is not matter: questions from 20 to 23 showed that corruption is not necessary to harm or attract attention every decision maker in the examined LNGOs and some of the directors and managers can deal with this issue as its not exist or as routine issue. This is one of the very negative outcomes of dealing with corruption carelessly:

a) Almost (48\%) of participants disagree that some directors and managers in LNGOs that they worked/ work with as a (donor, partner or staff) will resign if corruption cases confirmed in the examined LNGOs. Almost half of participants in the survey are convinced that practically the current applied Code of conduct / internal policy in the involved LNGOs have shortage in determining corruption behaviors or fighting corrupters.

b) Above $(50 \%)$ of participants agreed that some directors and managers in the LNGOs that they worked/ work with as a (donor, partner or staff) will stay even if corruption cases confirmed.

c) Above $(57 \%)$ of participants agreed that the examined LNGOs that they worked/ work with as a (donor, partner or staff) do not mind to receive fund from entities listed as corrupted. Workers in humanitarian field should be aware and carefully listen to this caution bell. This research even if it was conducted in specific geographic area, but there is a high possibility to be repeated in similar societies and other areas and in turn leads to global challenge.

d) Almost (55\%) of the participants agreed that the examined LNGOs that they worked/work with as a (donor, partner or staff) do not mind to deal with entities listed as corrupted. This result should attract the donors' attention to build professional relationship with the organizations that they fund to ensure healthy and correct spending of the fund. On the other hand the donors should take care about their administration and professional reputation. Donors should double check that the fund receivers are clearly and practically reflect the donor global values and morals.

Generally the above results are in line with the obtained results from the first package of questions from 5 to 11 and the code of conduct/ internal policy: a) does not reflect the real need of the organization, b) were not prepared by qualified staff, c) organization staff feedback were not took into consideration in developing the code of conduct / internal policy, d) are subjected to personal justifications regardless the standard criteria and the updating processes of code of conduct and internal policy do not reflect the reality needs of the organization. 
5. Recommendations: this package of questions showed part of the participants challenge to work in healthy and professional work environments. The answers were evidence on observing corruption and looking for solution.

a) Above $95 \%$ of participants agree with recommendation of conducting periodical technical testing of the employees is an efficient technique to stop corruption recruiting processes. This step will contribute in uncovering any none technical or ethical behaviors during recruiting processes especially during interview session and closing the opportunity to getting advantage from interview session to select staff based on favoritism or personal judgment. Also it shows the capacity of HR staff in reviewing and submitting the most qualified staff to the organization management.

b) Above $98 \%$ of participants agreed with recommendation of enhancing the transparency during the technical testing processes through adding an external third part which will be identified by the donors and appointing a technical advisor from the donor to overview the transparency of the procedures to control the corruption possibilities in the LNGOs. Meanwhile above $96 \%$ of the participants agreed that engaging a technical member from the donors to recruitment panel will reduce corruption possibilities in the employment processes or selecting the vendors. These steps will minimize any hidden or unofficial agreement used to be conducted inside the organization between the program department and HR unit to select the new staff or between the procurement department and vendors to give the bits to specific agency or contractor. The donor close directing engaging will ensure accepted reliability and an effective mechanism to spend the allocated fund without causing any abusing of the authorities inside the organization.

c) Above $97 \%$ of the respondents agreed with recommendation of installing online complaint screens to submit corruption cases and to be reviewed directly by HQ to control abusing of the authorities or misleading inside the LNGOs. This step will unfold any possibilities of prepared scenarios or fake excuses to terminate or releasing staff. On the other hand this tool will support the LNGOs management to update the organization code of conduct / internal policy more efficiently.

d) Above $98 \%$ of participants agreed with the recommendation that says: The relationship between the donors and the LNGOs should not be limited to financial support or reviewing the annual reports. This point will contribute significantly in solving many issues inside the LNGOs as the donor will:

i) Sharing their best practice with the LNGOs.

ii) Closely responding to the update and reacting properly to safe the fund and both organizations reputation.

iii) Minimizing any personal attempts to misusing the authority inside the organization or misleading the staff to cause staff liquidation and later appointing new staff and build internal clique. It should be part donors' responsibility to check the employee history of any organization requests fund or financial support.

iv) Capacity building: strengthen the recruiting processes in LNGOs in Iraq as adding external resource to communication with the donor side regarding any complaining, engaging the donor or partners more in the hiring panel, conducting test of the recruited staff as a technique to stop corruption in recruiting processes or selecting vendors and also to control any favoritism during the interview sessions. Last but not least unify the interview duration and the addressed questions especially that some interview sessions are arranged just pretend that the processes are done and there is no previous selected person for the announced position. Today it became part of reality that jobseekers call to find out if the position has been occupied previously or it worth to submit their CVs.

6. I do not know: the survey showed that the high rate of the participants does not know about the organization code of conduct and internal policy. This rate as explained in table (6) shows the huge gap between the efficiency of implemented activities in the reality and the organization management board.

\section{Limitation:}

Using online survey as a tool to collect data is somehow new in Iraq meanwhile it was adopted as the most protected way to ensure secure and transparent feedback. Due to the sensitivity of the issue, the collected 
data of this survey conducted through online service to give the participants all the space to answer freely and protect the respondents from any potential abusing or misleading by their supervise.

\section{Further Research:}

This paper could be considered as one of the first attempts to conduct researches on the effectiveness of transparency in the LNGOs and minimizing corruption through emphasizing on the quality of program rather than requesting makeup data to convince the donors to give further funds.

\section{Conclusion:}

The obtained results showed that notable level of corruption is exist in examined LNGOs and there is no effectiveness implementing code of conduct / internal policy that prevent corruption.

Level of corruption could be noted in the LNGOs and based on the collected data this corruption is result of: a) lack of comprehensive and professional code of conduct / internal policy, b) absent of best practice and international criteria in managing and producing organization issues at daily bases which lead to some shortages as: 1) some directors and managers negatively abusing the authorized power of their positions for their personal advantage regardless the humanitarian principles in the LNGOs,2) staff do not feel responsible to inform about corruption practice and more worse is they do not feel shy, shame or embarrassed from approving or practicing corruption in their work areas, and these behaviors' lead to 3 ) to be corrupted or not corrupted will not make big different as some of the corrupted directors and managers will remain in their positions if even their corruption cases confirmed.

Based on the participants feedbacks: INGOs are recommended to support building professional work environment in the LNOGs to establish productive work environment to share the best practice and developing the personal capacity in the LNGOs which includes but not limited to: designing clear and identified goals and objectives, determining and identifying the role and responsibilities of the directors and managers to ensure healthy practicing to their role among the staff, developing and protecting the organization principles and methodologies against individual interventions.

\section{References:}

[1] Adam Graycar Aiden Sidebottom, (2012),"Corruption and control: a corruption reduction approach", Journal of Financial Crime, Vol. 19 Iss 4 pp. 384 - 399. AF:

http://www.emeraldinsight.com/doi/pdfplus/10.1108/13590791211266377.

[2] Ahmed Seleim Nick Bontis, (2009),"The relationship between culture and corruption: a crossnational study", Journal of Intellectual Capital, Vol. 10 Iss 1 pp. 165 - 184. AF:

http://www.emeraldinsight.com/doi/pdfplus/10.1108/14691930910922978.

[3] Aimao Zhang, (2009),"Corruption as a determinant of transaction governance structure", Strategic Outsourcing: An International Journal, Vol. 2 Iss 1 pp. 27 - 36. AF:

http://www.emeraldinsight.com/doi/pdfplus/10.1108/17538290910935873.

[4] Asad Zaman Faiz-Ur-Rahim, (2009),"Corruption: measuring the unmeasurable", Humanomics, Vol. 25 Iss 2 pp. 117 - 126. AF:

http://www.emeraldinsight.com/doi/pdfplus/10.1108/08288660910964184.

[5] Ben Tran, (2008),"Corporate ethics: an end to the rhetorical interpretations of an endemic corruption", Social Responsibility Journal, Vol. 4 Iss 1/2 pp. 63 - 81. AF:

http://www.emeraldinsight.com/doi/pdfplus/10.1108/17471110810856848.

[6] Beverlee B. Anderson , (2015),"Corrupting activities and economic development", World Journal of Entrepreneurship, Management and Sustainable Development, Vol. 11 Iss 1 pp. 64 - 70. AF:

http://www.emeraldinsight.com/doi/pdfplus/10.1108/WJEMSD-07-2014-0020.

[7] David Ng, (2006),"The impact of corruption on financial markets", Managerial Finance, Vol. 32 Iss 10 pp. 822 - 836. AF: http://www.emeraldinsight.com/doi/pdfplus/10.1108/03074350710688314.

[8] Dennis C. McCornac, (2012),"The challenge of corruption in higher education: the case of Vietnam", Asian Education and Development Studies, Vol. 1 Iss 3 pp. 262 - 275. AF: http://www.emeraldinsight.com/doi/pdfplus/10.1108/20463161211270482.

[9] Ewan Sutherland, (2012),"Corruption in telecommunications: problems and remedies", info, Vol. 14 Iss 1 pp. 4 - 19. AF: http://www.emeraldinsight.com/doi/pdfplus/10.1108/14636691211196914. 
[10] G. Scanlan, (2004),"The control of corruption", Journal of Financial Crime, Vol. 11 Iss 4 pp. 316 321. AF: http://www.emeraldinsight.com/doi/pdfplus/10.1108/13590790410809257.

[11] Helmut Egesa Wagabi , (2013),"Fighting corruption successfully", The TQM Journal, Vol. 25 Iss 5 pp. 577 - 579. Af: http://www.emeraldinsight.com/doi/pdfplus/10.1108/TQM-09-2012-0071.

[12] Hendi Yogi Prabowo , (2014),"To be corrupt or not to be corrupt", Journal of Money Laundering Control, Vol. 17 Iss 3 pp. 306 - 326. Available from http://www.emeraldinsight.com/doi/pdfplus/10.1108/JMLC-11-2013-0045.

[13] Michel Dion, (2010),"Corruption and ethical relativism: what is at stake?", Journal of Financial Crime, Vol. 17 Iss 2 pp. 240 - 250. AF:

http://www.emeraldinsight.com/doi/pdfplus/10.1108/13590791011033926

[14] Michel Dion, (2010),"What is corruption corrupting? A philosophical viewpoint", Journal of Money Laundering Control, Vol. 13 Iss 1 pp. 45 - 54. Available from:

http://www.emeraldinsight.com/doi/pdfplus/10.1108/13685201011010209.

[15] Noel Campbell Adriana S. Cordis , (2014),"Expected corruption and business formation", Journal of Entrepreneurship and Public Policy, Vol. 3 Iss 2 pp. 292 - 305. AF:

http://www.emeraldinsight.com/doi/pdfplus/10.1108/JEPP-06-2013-0026.

[16] Olatunde Julius Otusanya, (2011),"Corruption as an obstacle to development in developing countries: a review of literature", Journal of Money Laundering Control, Vol. 14 Iss 4 pp. 387 - 422. AF: http://www.emeraldinsight.com/doi/pdfplus/10.1108/13685201111173857.

[17] Shinichiro Tanaka, (2001),"Corruption in education sector development: a suggestion for anticipatory strategy", International Journal of Educational Management, Vol. 15 Iss 4 pp. 158 - 166. AF: http://www.emeraldinsight.com/doi/pdfplus/10.1108/09513540110394384.

[18] Tanja Rabl Torsten M. Kühlmann, (2009),"Why or why not? Rationalizing corruption in organizations", Cross Cultural Management: An International Journal, Vol. 16 Iss 3 pp. 268 - 286. AF: http://www.emeraldinsight.com/doi/pdfplus/10.1108/13527600910977355.

[19] Tesfaye T. Lemma , (2015),"Corruption, debt financing and corporate ownership", Journal of Economic Studies, Vol. 42 Iss 3 pp. 433 - 461. AF:

http://www.emeraldinsight.com/doi/pdfplus/10.1108/JES-02-2013-0029.

[20] Yong Guo Songfeng Li , (2015),"Anti-corruption measures in China: suggestions for reforms", Asian Education and Development Studies, Vol. 4 Iss 1 pp. 7 - 23. AF:

http://www.emeraldinsight.com/doi/pdfplus/10.1108/AEDS-10-2014-0048. 